\title{
Robertsonian chromosome polymorphism found in a local herd of the Japanese Black cattle
}

\author{
H. HANADA, S. MURAMATSU, T. ABE and T. FUKUSHIMA * \\ Department of Animal Breeding and Genetics, \\ National Institute of Animal Industry, \\ Tsukuba Norindanchi, P.O. Box 5, Ibaraki-ken, PC 305, Japan \\ * Faculty of Agriculture, Kobe University, Kobe, PC 657, Japan
}

\begin{abstract}
Summary
The cytogenetic survey was carried out on a hord of the Japanese Black breed in the western region of Japan. The chromosome translocations of Robertsonian type were observed in 18 of 112 animals analysed (16.1 p. 100). Two kinds of translocations were identified by G-banding techniques. One translocation involved chromosomes 1 and $29(1 / 29$ translocation) and the other involved chromosomes 7 and $21(7 / 21$ translocation). Three out of 18 carriers were the $1 / 29$ translocation heterozygotes with $2 \mathrm{n}=59, \mathrm{XX}, \mathrm{t}$ (lq 29q). Fourteen animals were the $7 / 21$ translocation carriers among which 12 were heterozygotes with $2 \mathrm{n}=59, \mathrm{XY}$ or $\mathrm{XX}, \mathrm{t}(7 \mathrm{q} 21 \mathrm{q})$ and two were homozygotes with $2 \mathrm{n}=58, \mathrm{XX}$, $t(7 q$ 21q) $t(7 q$ 21q). The remaining one animal was a double heterozygote carrying the $1 / 29$ and the $7 / 21$ translocations. Based on the C-banding analysis, it was confirmed that the translocated chromosomes $1 / 29$ and $7 / 21$ were monocentric and dicentric, respectively. All the carriers were phenotypically normal and appeared healthy.
\end{abstract}

\section{1. - Introduction}

The Robertsonian translocation in cattle was first reported as the $1 / 29$ translocation which was resulted from a centric fusion between the largest and the smallest autosomes in the Swedish Red and White breed (Gustavsson \& RocKBORN, 1964). Since then, the same or other types of Robertsonian translocations have been found in many breeds. In the Japanese Black breed, the presence of two kinds of Robertsonian translocations has been confirmed by MASUDA et al. (1978, 1980) and by HANADA et al. (1979).

As to the effect of these translocations on reproductivity and viability, however, results are still conflicting even of the $1 / 29$ translocation which is distributed widely in the world (Amrud, 1969; Gustavsson, 1969 and 1979; Pollock \& Bowman, 1974 ; REFSDAL, 1976). To evaluate the significance of these Robertsonian translocations, it seemed necessary to know the distribution and frequency of such translo- 
cations in particular population. The present report is concerned with the frequency of the $1 / 29$ and the $7 / 21$ translocations in the Japanese Black Cattle.

\section{2. - Materials and methods}

Blood samples were obtained from 112 animals raised in farms of the western region of Japan. Each sample $(0.5 \mathrm{ml})$ was incubated at $37^{\circ} \mathrm{C}$ for $72 \mathrm{hrs}$ in $5 \mathrm{ml}$ of RPMI-1640 medium supplemented with 15 p. cent fetal calf serum (GIBCO), PHA (Welcome) and antibiotics. One droplet of colchicine solution was added at $2.0 \mathrm{hrs}$ before the termination of culture. After hypotonic treatment with 0.5 p. cent $\mathrm{KCl}$ solution, cells were fixed in metanol-acetic acid (3:1), and air-dried on a slide glass. Trypsin G-band technique was applied to the identification of the chromosome pairs (Seabright, 1971). Heterochromatin was stained by the BSG method of Sumner (1972). A total of 20 metaphase cells from each animal was analysed with the ordinary non-banding method. Those with abnormal complements were further studied by $\mathrm{G}$ - and $\mathrm{C}$-banding methods.

\section{3. - Results and discussion}

The diploid chromosome number of the Japanese Black Cattle was $2 n=60$. The diploid complement consists of 29 pairs of acrocentric autosomes and one pair of sutmetacentric sex chromosomes as seen in all the other breeds of European Cattle. The present chromosome analysis was based on the G-band karyotype established by the standard numbering system (Ford et al., 1980).

TABLE 1

Results of cytogenetic analyses

Résultats des analyses cytogénétiques

\begin{tabular}{|c|c|c|}
\hline Chromosome number and karyotype & $\begin{array}{l}\text { Number } \\
\text { of animals }\end{array}$ & Percentage \\
\hline $2 n=60, X Y$ or $X X$, Normal & 94 & 83.9 \\
\hline $2 \mathrm{n}=59, X X, \mathrm{t}(1 \mathrm{q} 29 \mathrm{q}) \ldots$ & 3 & 2.7 \\
\hline $2 \mathrm{n}=59, X Y$ or $X X, t(7 q 21 q)$ & 12 & 10.7 \\
\hline $2 \mathrm{n}=58, X X, \mathrm{t}(7 \mathrm{q} 21 \mathrm{q}) \mathrm{t}(7 \mathrm{q} 21 \mathrm{q}) \ldots$ & 2 & 1.8 \\
\hline $2 \mathrm{n}=58, X X, \mathrm{t}(1 \mathrm{q} 29 \mathrm{q}) \mathrm{t}(\mathrm{(q} 21 \mathrm{q}) \ldots \ldots \ldots \ldots$ & 1 & 0.9 \\
\hline Total & 112 & 100.0 \\
\hline
\end{tabular}


Out of 112 cattle examined, 94 animals had the normal karyotype with $2 n=60$, $\mathrm{XY}$ or XX (table 1). The remaining 18 cattle showed a reduction of the diploid number from 60 to 59 or 58 chromosomes in all the cells studied and one or two large submetacentric chromosomes were also observed in their metaphases. Based on the results of karyotype analysis with G-banding techniques, it was confirmed that such large submetacentric chromosomes were resulted from reciprocal translocations between the entire arms of a large and a small acrocentric autosomes. Two kinds of translocations were identified. One translocation designated as the $1 / 29$ translocation involved the largest and the smallest chromosomes 1 and 29, respectively. The long and the short arms of the translocation chromosome were easily identified as chromosomes 1 and 29, respectively, by their sizes and characteristic banding patterns (fig. 1). The other was the autosomal translocation between chromosomes 7 and 21 , and designated as the $7 / 21$ translocation.
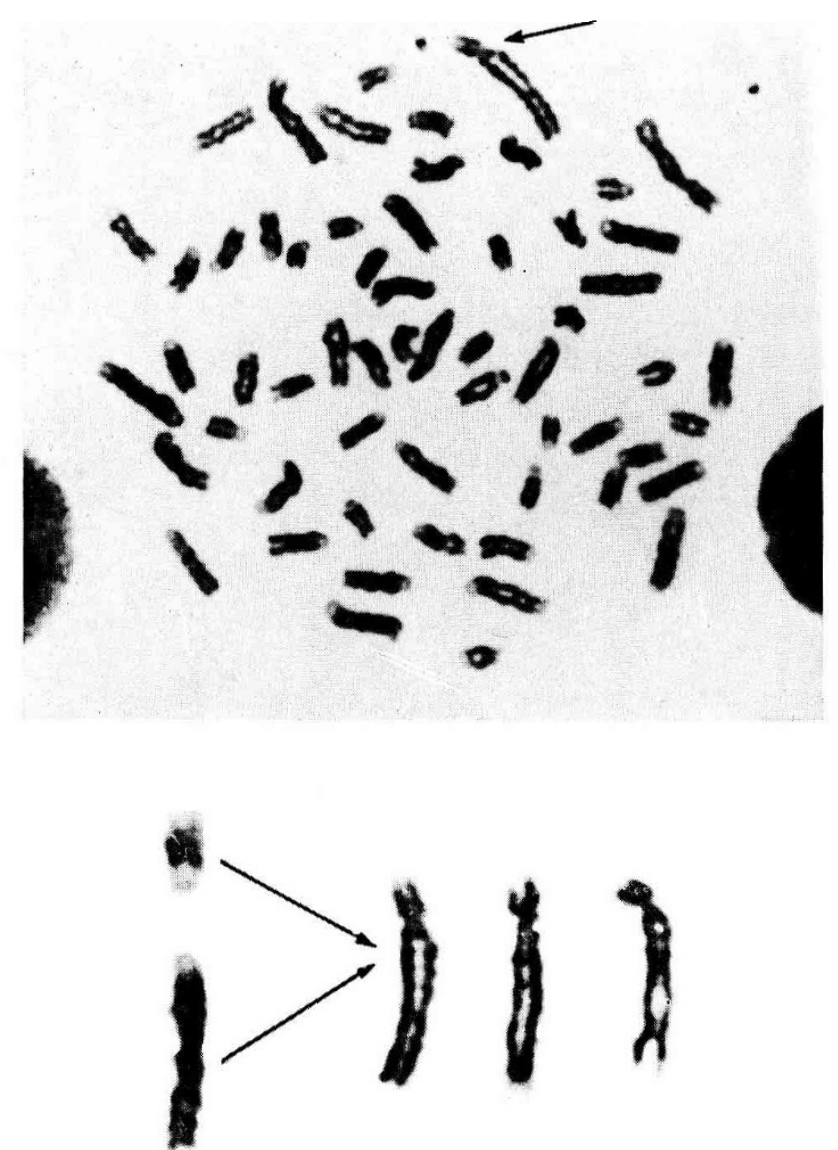

FIG. 1

$G$-banded metaphase of a cell carrying the 1/29 translocation (arrow) and the fused chromosomes from three different carriers

Métaphase en bandes $G$ d'une cellule porteuse de la translocation 1/29 (flèche) et chromosomes fusionnés des trois différents porteurs 
The long arm of the translocation chromosome was identified as chromosome 7 by its size and five distinct positive bands among which two proximal bands were very dark and the most proximal one was the narrowest. The short arm of translocation chromosome was also identified as chromosome 21 by banding patterns such as two distinct dark bands with a very pale intervening band (fig. 2).
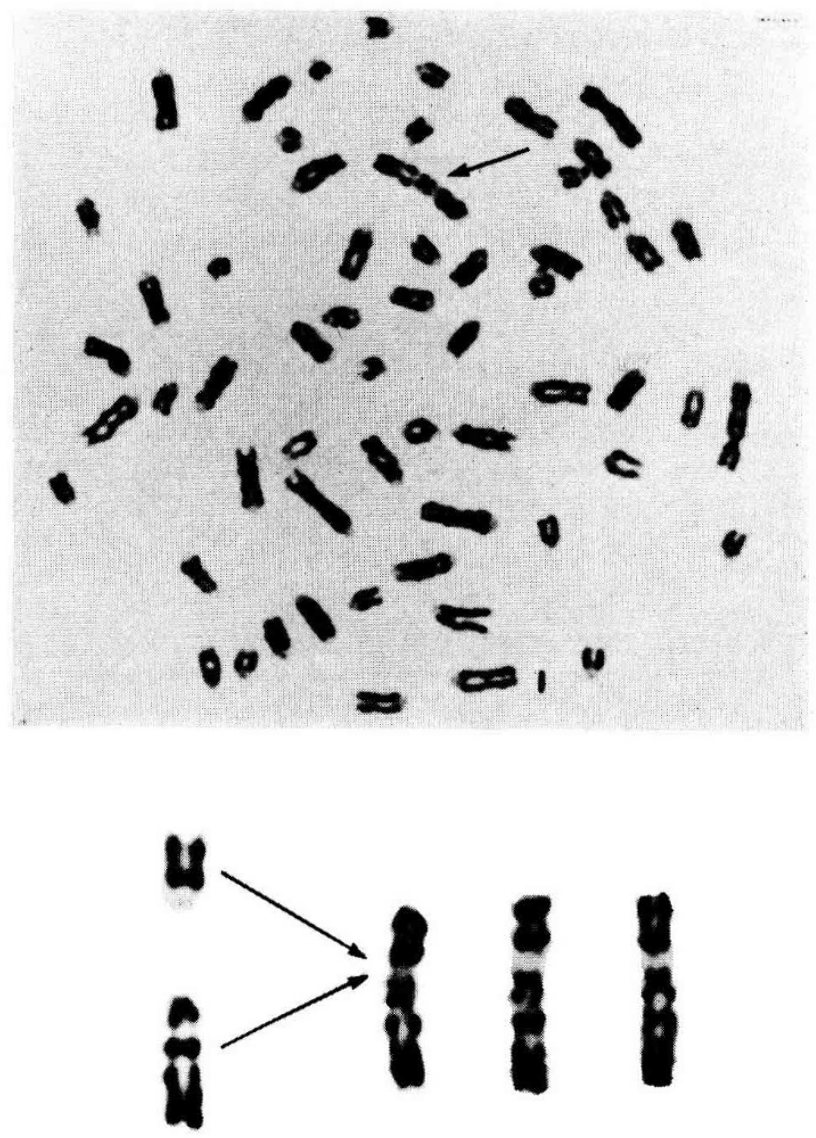

FIG. 2

G-banded metaphase of a cell carrying the 7/21 translocation (arrow) and the fused chromosomes from three different carriers

Métaphase en bandes $G$ d'une cellule porteuse de la translocation $7 / 21$ (flèche) et chromosomes fusionnés des trois différents porteurs

The C-banding patterns of these two kinds of translocations are shown in figure 3. The $1 / 29$ translocation chromosome was a monocentric with the single centromere on the long arm side of the point of fusion, while the $7 / 21$ translocation was a dicentric chromosome which had the double centromeres on the both long and short arm sides of the point of fusion. 
The detailed karyotype analysis for 112 cattle are summarized in table 1 . Three out of 18 carriers were the $1 / 29$ translocation heterozygotes with $2 \mathrm{n}=59, \mathrm{XX}, \mathrm{t}$ (1q 29q). Fourteen animals were $7 / 21$ translocation carriers among which 12 were heterozygotes with $2 \mathrm{n}=59, \mathrm{XY}$ or $\mathrm{XX}, \mathrm{t}(7 \mathrm{q} 21 \mathrm{q})$ and two were homozygotes with $2 \mathrm{n}=58, \mathrm{XX}, \mathrm{t}(7 \mathrm{q} 21 \mathrm{q}) \mathrm{t}(7 \mathrm{q} 21 \mathrm{q})$. The remaining one animal was a double heterozygote carrying the two types of translocations; $2 \mathrm{n}=58, \mathrm{XX}, \mathrm{t}$ (1q 29q) $t$ (7q 21q). The frequencies of the $1 / 29$ and the $7 / 21$ translocation carriers were $3.9 \mathrm{p}$. cent and $14.4 \mathrm{p}$. cent, respectively. The former translocation was contributed by one carrier bull and the latter by five carrier bulls.
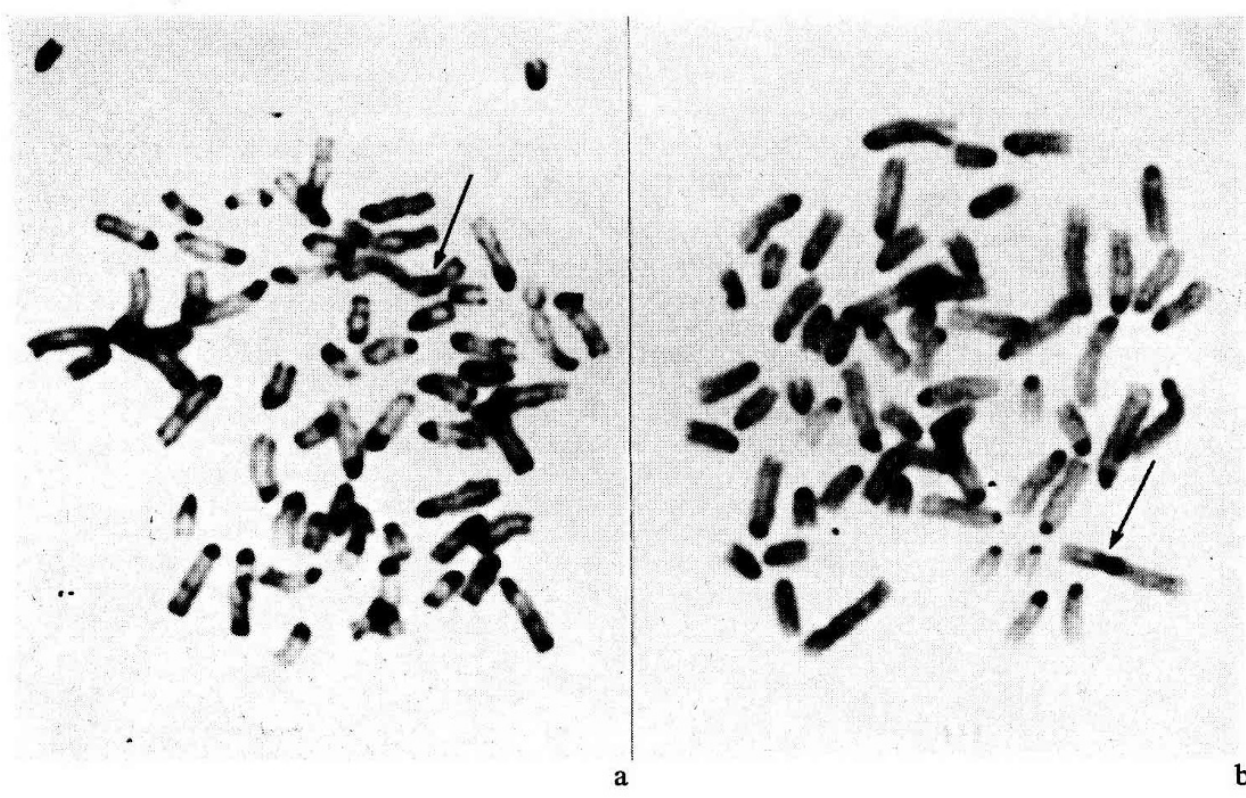

FIG. 3

Metaphases of C-bands treated cells carrying the $1 / 29$ (a) or the $7 / 21$ (b) translocation. Arrow shows the translocation chromosome

Métaphases en bandes $C$ des cellules portant la translocation 1/29 (a) ou 7/21 (b). La translocation est marquée par une flèche

The 1/29 translocation was found in many breeds throughout the world with about $6.0 \mathrm{p}$. cent of average frequency (HARVEY, 1976). The presence of a single centromere in the same translocation was confirmed in several other breeds (PoPESCU, 1973 ; Gustavsson et al., 1976 ; BlazaK \& Eldridge, 1977). On the other hand, the 7/21 translocation was first reported by MASUDA et al. (1978) as the 5/21 translocation in one bull and his eight progenies. Thereafter, the same translocation was observed in a breeding herd with a fairy high frequency (HANADA et al., 1979) and also in one of heterosexual twin with freemartin syndrome (Окамото et al., 1981). This translocation has not yet been reported in the other breeds. 
Considering its distribution and C-banding patterns, it may be suggested that the $7 / 21$ dicentric translocation occurred recently in the Japanese Black breed, while the $1 / 29$ monocentric translocation took place much earlier.

All the carriers in this study were phenotypically normal, and no abnormality was observed on the condition of their health. To evaluate the potential effects of these translocations on the other economic traits, the further analyses are in progress now.

$$
\text { Reçu pour publication en juillet } 1981 .
$$

\section{Résumé \\ Polymorphisme chromosomique du type robertsonien trouvé dans un troupeau de la race bovine Noire Japonaise}

Un examen cytogénétique a été réalisé dans un certain troupeau de race Noire Japonaise dans la région ouest du Japon. Les translocations du type robertsonien ont été observées chez 18 des 112 animaux examinés (16.1 p. 100). Parmi les translocations observées deux sortes des fusions centriques ont été distinguées par la méthode des bandes G. L'une était la translocation $1 / 29$, et l'autre était la translocation $7 / 21$. Trois parmi 18 porteuses de ces translocations étaient hétérozygotes pour la translocation $1 / 29: 2 \mathrm{n}=59$, $X X, t$ (1q 29q). Quatorze présentaient la translocation $7 / 21: 12$ hétérozygotes, $2 \mathrm{n}=59$, $\mathrm{XY}$ ou $\mathrm{XX}, \mathrm{t}(7 \mathrm{q} 21 \mathrm{q})$, et 2 homozygotes, $2 \mathrm{n}=58, \quad \mathrm{XX}, \mathrm{t}(7 \mathrm{q} 21 \mathrm{q})$ t (7q 21q). Enfin une vache était à la fois hétérozygote pour les translocations $1 / 29$ et $7 / 21$. L'analyse des bandes $\mathrm{C}$ a confirmé que les chromosomes qui ont montré les translocations $1 / 29$ et $7 / 21$ sont les chromosomes monocentrique et dicentrique, respectivement. Tous les animaux porteurs de ces translocations étaient phénotypiquement normaux et apparaissaient sains.

\section{References}

AmRud J., 1969. Centric fusion of chromosomes in Norwegian Red Cattle (NRF). Hereditas, 62, 293-302.

Blazak W.F., Eldridge F.E., 1977. A Robertsonian translocation and its effect upon fertility in Brown Swiss cattle. J. Dairy Sci., 60, 1133-1142.

Ford C.E., Pollock D.L., Gustavsson I. (eds), 1980. Proceeding of the First International Conference for the Standardisation of Banded Karyotypes of Domestic Animals. Hereditas, 92, 145-162.

Gustavsson I., RockBoRN G., 1964. Chromosome abnormality in three cases of lymphatic leukemia in cattle. Nature, 203, 990.

Gustavsson I., 1969. Cytogenetic, distribution and phenotypic effects of a translocation in Swedish cattle. Hereditas, 63, 68-169.

Gustavsson I., Hageltorn M., Zech L., 1976. Identification of the 1/29 translocation in the Swedish Red and White (SRB) Cattle breed by utilization of new staining techniques. Hereditas, 82, 260-262.

Gustavsson I., 1979. Distribution and effects of the $1 / 29$ Robertsonian translocation in cattle. J. Dairy Sci., 62, 825-835. 
Hanada H., Muramatsu S., Abe T., Himeno K., 1979. Chromosome polymorphism in a herd of the Japanese Black Cattle. Paper presented at the 70th Annual Meeting of the Japanese Society of Zootechnical Science (August 28-29, 1979, Shinshu University, Matsumoto, Japan), 64.

HARVeY M.J.A., 1976. Veterinary cytogenetics. Vet. Rec., 98, 479-481.

Masuda H., Takahashi T., Soejima A., Waide Y., 1978. Centric fusion of the chromosomes in a Japanese Black bull and his offsprings. Jpn. J. Zootech. Sci., 49, 853-858.

Masuda H., Shioya Y., Fukuhara T., 1980. Robertsonian translocation in Japanese Black Cattle. Jpn. J. Zootech. Sci., 51, 26-32.

Okamoto A., Yoshizawa M., Muramatsu T., 1981. Studies of the Robertsonian translocation in Japanese Black Cattle. Bull. Coll. Agric. Utsunomia Univ., 11, 1-8.

Pollock D.L., Bowman J.C., 1974. A Robertsonian translocation in British Friesian cattle. J. Reprod. Fert., 40, 423-432.

Popescu C.P., 1973. L'hétérochromatine constitutive dans le caryotype bovin normal et anormal. Ann. Génét., 16, 183-188.

Refsdal A.O., 1976. Low fertility in daughters of bulls with $1 / 29$ translocation. Acta Vet. Scand., 17, 190-195.

Seabright M., 1971. A rapid banding technique for human chromosomes. Lancet, II, 971-972.

SUMNer A.T., 1972. A simple technique for demonstrating centromeric heterochromatin. Exp. Cell Res., 75, 304-306 